\title{
Challenges of Rural Landscape Mosaic and Beautification in Oku, North West Region of Cameroon
}

\author{
Godwill Tobouah Nyanchi ${ }^{1}$, Kiming Ignatius Ngala ${ }^{1}$, Nyuyki Bernard Bodzemo ${ }^{1}$, \\ Akoni Innocent Ngwainbi ${ }^{1}$, George Ngek Diom ${ }^{2}$ \\ ${ }^{1}$ Department of Geography, Faculty of Arts, Letters and Social Sciences, University of Yaounde 1, Yaounde, Cameroon \\ ${ }^{2}$ Department of Sociology, Faculty of Arts, Letters and Social Sciences, University of Yaounde 1, Yaounde, Cameroon
}

Email address:

goddy288@yahoo.com (G. T. Nyanchi), ignatiusngalakiming@gmail.com (K. I. Ngala), nyuykiberardbodzemo@yahoo.fr (N. B. Bodzemo), alljusticeyuh@gmail.com (A. I. Ngwainbi),georgengek@yahoo.fr (G. N. Diom)

\section{To cite this article:}

Godwill Tobouah Nyanchi, Kiming Ignatius Ngala, Nyuyki Bernard Bodzemo, Akoni Innocent Ngwainbi, George Ngek Diom. Challenges of Rural Landscape Mosaic and Beautification in Oku, North West Region of Cameroon. International Journal of Science and Qualitative Analysis. Vol. 6, No. 1, 2020, pp. 1-7. doi: 10.11648/j.ijsqa.20200601.11

Received: November 18, 2019; Accepted: December 11, 2019; Published: April 17, 2020

\begin{abstract}
Rural landscapes are predisposed to a wide range of challenges and changes. These changes modify and transform rural setting rendering them desirable for habitation. Backed by a montane forest rich in biodiversity and other resources, the locale is blessed to possess a volcanic crater lake of exceptional beauty and attraction. The objective of this study is to appreciate the challenges of landscape assortment and beautification of a typical rural setting. Over the years, the rate of countryside transformation is on the rise. The primary method of information collection on the subject under study focused on first hand data from rural inhabitants. Questionnaires were administered residents of the study area. The questionnaires focused on ways of transformation of the rural area, duration, materials used and sources. The open and close ended question technique was adopted. Direct field observation and numerous visits to the study area were undertaken. Results obtained revealed the rapid rate of rural landscape transformation, the high rate of tourist visits and a beautification of the countryside. The study concluded that natural and human influences on the landscapes accounts for beautification.
\end{abstract}

Keywords: Rural, Landscape, Mosaic, Embellishment

\section{Introduction}

Primary activities dominate in rural communities and remain the economic back bone of this society. The growing food demands within the study area attracts the planting of different species of trees ranging from fruit trees, ornamental species, suitable trees for wood carving, artificial fencing and trees for roofing. Widespread construction of houses with different type and quality of materials adds more variance on the outlook of the area. As a matter of fact, tree planting along the slopes of Mount Oku has really gained grounds over the years. In addition, both primary and secondary schools within the area are not left out in the tree planting exercise. The practice of agro forestry therefore touches all ages and all classes of people within the locality. Tree planting therefore remains an integral part of agro forestry within $\mathrm{Oku}$ and should be highly encouraged. It greatly rekindles hope in agriculture which is considered as the mainstay of the society. According to field experience, about $70 \%$ of local farmers in $\mathrm{Oku}$ can now boast of active participation in one of the activities geared at improving livelihoods. The majority of farmers today in Oku are no longer conservatives. Their open-minded nature makes the locale attractive to foreign visitors. A plethora of tourists are registered in the area duly as a result of her natural and artificial landscape.

In addition to the numerous traditional forms of landscape transformation, agro forestry practices in one way shape the entire landscape of Oku. The area is shaped with a mosaic dominated by intensive seasonal cultivation on different plots. The study further reveals that farmers practice agro forestry because of the numerous benefits they derive from it. This strategy provides a simultaneous agro forestry alternative for integrating agriculture and forestry components in the landscape. Even though the farmlands are 
acquired through different means, the farmers share a common goal of obtaining maximum outputs and profits from the farms. These efforts in a nutshell assess the place of agro forestry within the locality where more than $80 \%$ of the population are involved in farming or related activities. However, the agro-ecosystems in Oku are under pressure from the ever-increasing population. With regard to this, it further limits substantial transformation in relatively short period of time. Today, the potential of agro forestry practices in landscape transformation is generally accepted. Indeed, agro forestry is fast becoming recognized as a system which is capable of reshaping rural areas and at the same time conserving and rehabilitating ecosystems.

\section{Research Methodology}

This study gathered much data from both primary and secondary methods. This was feasible thanks to a mastery of the matrix area. Methods adopted suited the content of the study carried out. Set goals were achieved at a relatively suitable time permitting a detailed analysis of results to be presented. Administration of questionnaires with the prime objective of collecting data was the leading technique adopted. Through this, both visible and invisible data were properly gathered. The advanced interpretation of landscape changes was confirmed from the exploitation of satellite images giving a picture of the high rate of observed over the years. As a matter of fact, interviews both formal and informal unequivocally confirmed this. Indeed, focus group discussions revealed strong evidence of landscape mosaic and beautification within this naturally rich and blessed locale.

\section{Results}

\subsection{Physical Background: A Naturally Consecrated Setting}

Nature has blessed this locale with numerous outstanding features. The general image of these potentials makes the landscape naturally beauty and attractive. The study area falls within latitude $6^{\circ} 5^{\prime}$ and latitude $6^{\circ} 15^{\prime}$ North of the equator and longitudes $10^{\circ} 20^{\prime}$ and $10^{\circ} 40^{\prime}$ 'East of the Greenwich meridian. Mount Oku $(3011 \mathrm{~m})$ is the second highest mountain in mainland West Africa. On this summit is found the most attractive Lake Oku.

\subsubsection{The Famous Mount Oku (Kilum Mountain) 3011m}

Situated along latitude $6^{\circ} 44^{\prime}$ and longitude $10^{\circ} 3$ ' E, this mountain is a composite dormant volcano whose last eruption is unknown. Mount Oku $(3011 \mathrm{~m})$ is found along the Cameroon volcanic line in the Western Highlands commonly referred to as the Bamenda Highlands. Mount Oku is the second highest peak in mainland West Africa after Mount Fako $(4100 \mathrm{~m})$. This highland is hilly and mountainous and remains one of the greatest tourists' sites in the area. In addition, the area is marked with steep slopes, high rock cliffs marked by waterfalls and cascades, deep valleys and gorges depicting a naturally beautiful and attractive landscape. Ascension to the summit gives a full appreciation of mountain magnificence rich in character and diversity.

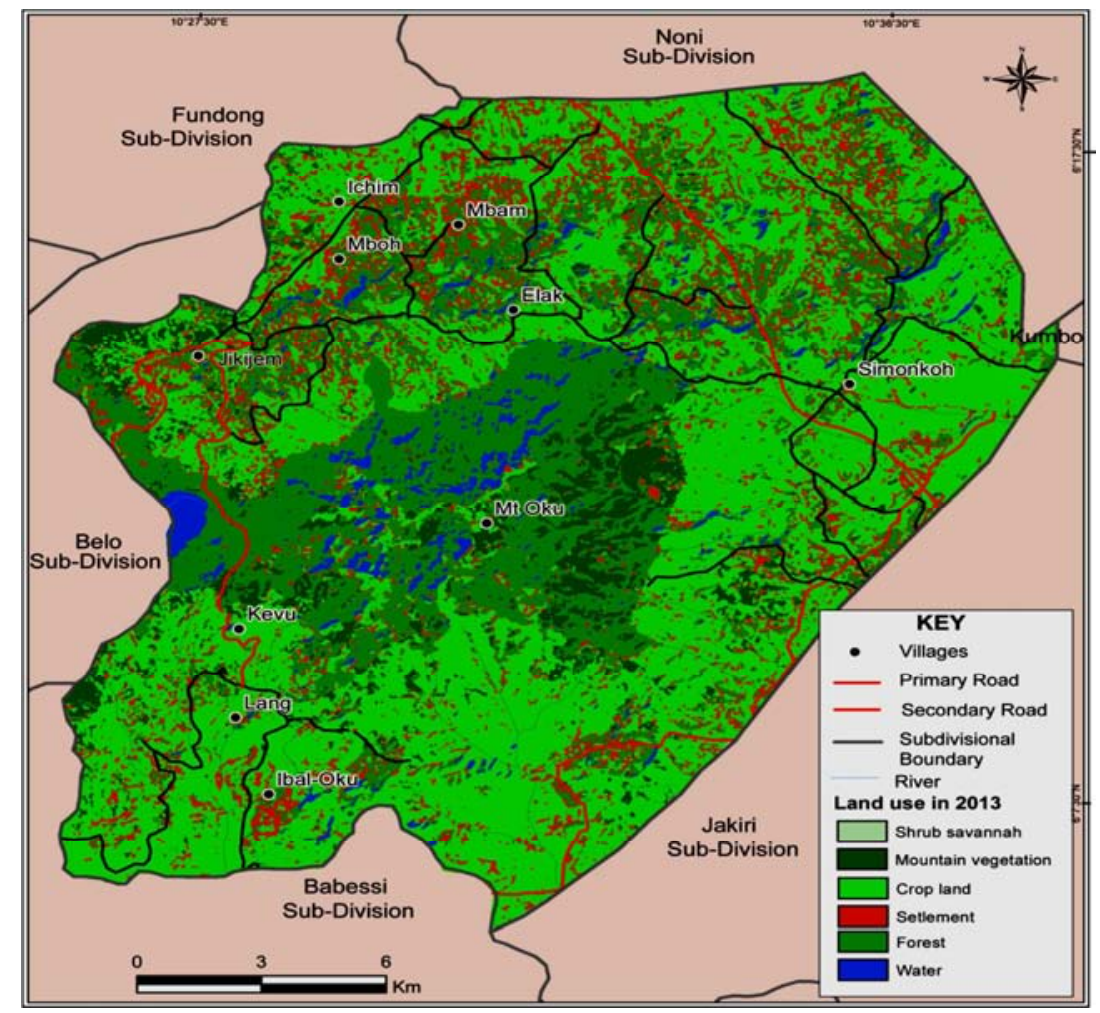

Source: Land sat Image 2019.

Figure 1. Land use and occupation of Oku. 
On the slopes of the Kilum Mountain is found the beautiful mountain vegetation with the existence of some rare plant species. This forest constitutes the last significant remnants of an ecosystem that is of global importance for conservation. Relevant species found here include: Gnida glauca, Maesa lanceolola, Hyperricum revelatum, Syzygium stautii, Agauria salicfolia, Nuxia congesta, Rapmea neuiphylia, Schefflera manni, poyscias fulve etc. The vegetation of the forest comprises more than 145 species of life forms [1]. The total area of the remaining forest is approximately 20.000 hectares [2]. Half is made up of montane forest and the rest montane grasslands characterised by various types of recolonisation formations [3]. The forest has suffered from serious deforestation in search for farmland, fuel, medicine, wood for carving, grazing and many other activities. The search for farmlands is responsible for the rapid deforestation of this montane forest. Forest conservation strategies put in place by the Kilum Mountain Forest Project limits encroachment. Figure 1 shows the landscape and land use nature of Oku.

The vegetation background is arranged in a succession along the slopes beginning from the lowest levels to the mountain summit. Between $1300 \mathrm{~m}$ and $1600 \mathrm{~m}$, dorminant vegetation is shrub savanna. Between $1500 \mathrm{~m}$ and $1900 \mathrm{~m}$ is made up of sporoborous grasslands. Above this region is the section of montane forest at 1900. Pure and Alpine bamboo characterises the region above $2300 \mathrm{~m}$ and extends up to $2800 \mathrm{~m}$ lastly, upland prairie is found above 2800 up to $3011 \mathrm{~m}$ as seen in figure 2 .

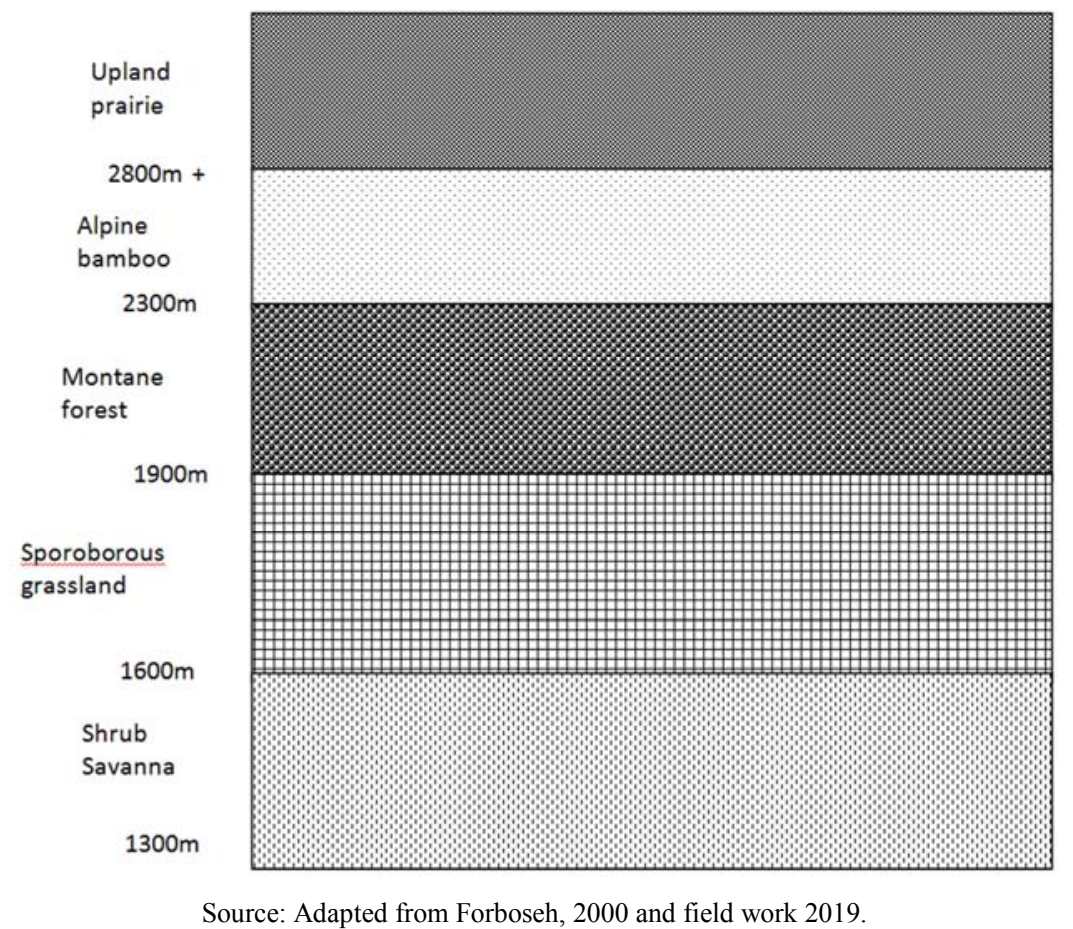

Figure 2. Stratification of vegetation along the slopes of Mount Oku.

\subsubsection{Picturesque Caves}

Caves are natural tourists sites numerously found in Oku. This area harbours many caves of different sizes and shapes. The volcanic intrusions of these caves are scenic features about $20 \mathrm{~m}$ deep and $30 \mathrm{~m}$ wide covered by large curved vault of rocks. The cave in Tolon a locality situated in the valleys is about $14 \mathrm{~m}$ deep and $10 \mathrm{~m}$ wide. It is situated $10 \mathrm{~m}$ from the waterfall. It is made up of enormous superimposed convex boulders. Inside the cave is found a perennial spring, cool clear and flowing out. The cave has a dark gallery with multiform vaults thus puncturing the landscape beautification of the area.

\subsubsection{Lake Oku: A Lake of Exceptional Quality}

Lake Oku (Mawes) is a volcanic lake situated at an altitude of $2450 \mathrm{~m}$ in the western part of the Kilum Mountain forest. It is situated in latitude $6^{\circ} 12^{\prime}$ north $10^{\circ} 27^{\prime}$ east. It is an important habitat for the Oku clawed toad xenopause specie, the migratory little grebe tachyhaptus ruficolis and the African black duck anas sparsa. Lake Oku is the most outstanding hydrographic feature in the area. The absence of an inlet into the lake creates curiosity in the minds of natives and visitors to the lake. The lake covers a total land surface area of $2.1 \mathrm{~km}^{2}$ with a max9mum length of $2 \mathrm{~km}$ and a minimum width of $1.5 \mathrm{~km}$. The lake has a diameter of $20 \mathrm{~m}$ [4].

\subsubsection{Deep Soils Suitable for Plant Anchorage}

Soil types in the area are heterogeneously distributed due to basement rock differences giving plant and tree anchorage a greater possibility. It is made up of ancient Precambrian basement complex rocks composed of granitic soils, trachytic soils, volcanic soils and basaltic soils. High lava plateau soils are mainly found at altitudes of 1800-2520m [5]. Landscape transformation is customized consequently as a result of deep 
soils etc. The growing of trees, cultivation of food crops and building of houses largely depends on the deep fine soil in present in $\mathrm{Oku}$ as seen in figure 2. This deep soil provides an anchorage where the roots can tap sufficient nutrients. There is a positive relationship between soil types and agricultural intensity.

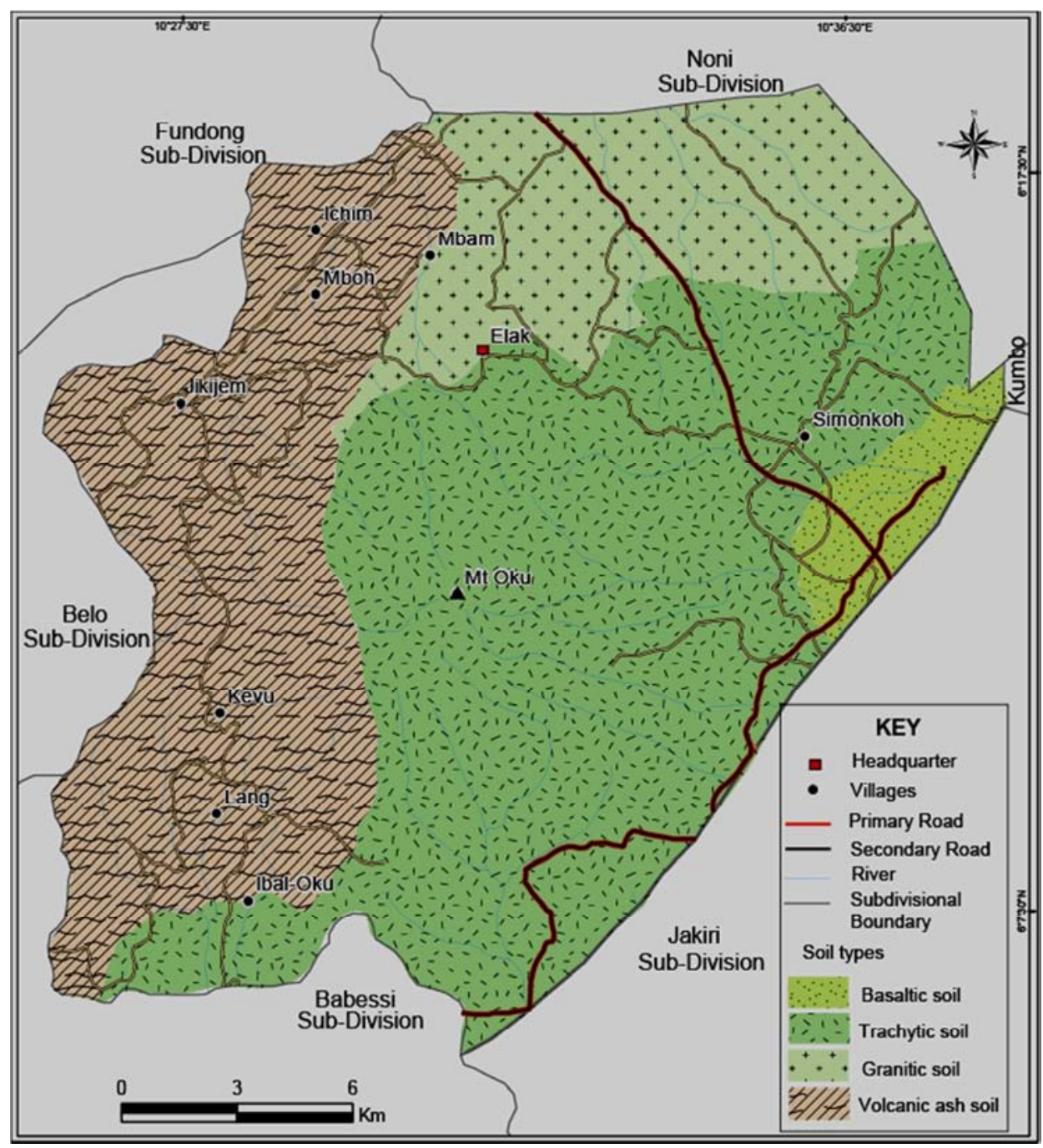

Source: Land sat 2017

Figure 3. Soil distribution map of Oku.

The area occupied by forest is dorminantly covered by trachytic soils. These soils have deep profiles anchoring tall and huge trees of about $6 \mathrm{~m}$. Deforestation prevails in neighbourhoods of Lui, Ngashie, Keyon, Mboh, Jikijem, Lang, Kevu and Kesotin with trachytic soils on the fringes of the forest. The fertility of these areas attracted the population to open farms for the cultivation of basic food crops thus modifying the entire landscape [6].

\subsection{Shrines and Sacred Areas Dotted on the Landscape}

The spiritual values of the people of Oku are synonymous with their cultural way of life. Culture is the way of life of a people. Sacred forests are places properly designed on the landscape and in such places monthly or yearly traditional worships or sacrifices are carried out. During such moments, tourists flow in to discover the rich nature of such sites. A glaring example is that of the traditional society (kwifon) that goes to lumetu (lumetu is the deity harbouring Mkong motehs shrine) and to lake Oku (Mawes) [7]. It is situated inside the Kilum mountain forest. In these places, traditional rituals are performed to please the gods. Sacred forests and shrines remain revered to the society. The natives fear to trespass in such places as there can be unfathomable consequences. These places are properly reserved and become luring arena for tourists and a habitat to many animals, snakes and scorpions. Another example of a shrine is the one found in Tolon. This deity and shrine is located near the water fall in Jikijem [8].

\subsection{Wood Carving: Promoting Tree Planting in Farms}

Wood carving stands as the warehouse of the peoples' culture and its sustainability has moved from generation to generation. Wood carving is an activity occupying more than $52 \%$ of youths in the area. Carvers are divided into three 
categories namely; full time and part time carvers. Full time carvers earn above $85 \%$ of their incomes from carving. Part timers earn between $10-70 \%$ of their incomes from carving [9]. With the restriction of cutting trees in the forest, these carvers now obtain suitable carving trees through buying from farmers. Close to $16 \%$ of the carvers plant trees their own trees thus contributing in transforming the rural landscape.

\subsection{Colonization of Marginal Lands}

The scarcity of cultivable lands has pushed needy farmers into areas which were hitherto not cultivated. Gallery forests found in valleys and the montane forests suffered human encroachments in the late 1990s. Isolated wetlands are constantly cultivated. Here, market gardening is the principal activity taking place. Thus the extension of farmlands into grazing lands, steep slopes, hills have greatly contributed in transforming the entire landscape.

\subsection{Scattered Trees on Farmland (Parkland Agro Forestry)}

Trees scattered haphazardly or according to some systematic patterns on bunds, terraces or plot/field boundaries, crop lands, pastures and rangelands can be viewed on the entire landscape of Oku. Some of the trees grow naturally from seeds dispersed by birds and other wildlife [10]. Such trees are retained by farmers during land preparation for agriculture, and are often randomly dispersed on the land. In the Sahel region of West Africa, scattered trees on cultivated or recently fallowed land forms a characteristic land-use system commonly referred to as 'Parklands'. The most important and dominant tree species in the parklands of the Sahel region include Faidherbia albida (syn. Acacia albida), Shea butter tree (Vitellaria paradoxa), Parkia biglobosa, Adansonia digitata (the baobab tree), and Tamarindus indica. Acacia tortilis and Prosopis species are also often scattered on the farmlands. Findings from this study show that scattered trees on farms in Oku include Caesalpiniaceae, Compositae, Euphorbiaceae, Mimosaceae, Leucaena diversifolia and many others. Through horticultural techniques, improved accessions of some of these species have been produced.

These accessions mature faster and produce higher-quality products than the existing natural populations in the parklands. Trees scattered on cropland offer a variety of benefits and these, together with the limitations of this agro forestry practice are listed below. Benefits of scattered trees on farmland include: such trees are considered by farmers not to be competitive against food crops, they provide shade for livestock during intense heat of the long dry season [11]. The trees diversify farmers' products and increase crop production, and the duration of cropping the land without fertilizer use and they control wind erosion when tree canopies in parklands intercept wind-blown soil. Indigenous trees for multipurpose reason occupy most farmlands in $\mathrm{Oku}$ as seen in table 1 .

Table 1. Indigenous trees for multipurpose reasons.

\begin{tabular}{|c|c|c|c|c|c|}
\hline Family & Species (latin name) & Oku name & Life form & Habitat & Use \\
\hline Araliaceae & Schefflera mannii & Ebwos, Kebongelengos & $\mathrm{Tt}$, ep & Fo & Tc, Ho \\
\hline Rosaceae & Prunus africana & Eblaa & $\mathrm{Tt}$ & Fo & $\mathrm{Md}, \mathrm{Tb}$ \\
\hline Compositae & Crossocephalum manni & Ngangang & St & $\mathrm{Sc}$ & $\mathrm{Ag}$ \\
\hline Solanceae & Solanum sp & Kelun & $\mathrm{Sb}$ & $\mathrm{Sc}$ & $\mathrm{Tr}, \mathrm{Md}$ \\
\hline Meliaceae & Carapa grandiflora & Ebven & $\mathrm{Tt}$ & Fo & Fw \\
\hline Mimosaceae & Albizia gummifera & Fuim & $\mathrm{Tt}$ & Fo & $\mathrm{Tb}, \mathrm{Ag}$ \\
\hline Euphobiaceae & Croton macrostachyus & Ebjam & $\mathrm{St}, \mathrm{tt}$ & Fo, sc & $\mathrm{Tc}, \mathrm{Ag}$ \\
\hline Moraceae & Ficus oreedryadum & $\mathrm{K}$ 'ghum fengak & $\mathrm{Tt}$ & Fo & $\mathrm{Tr} F e$ \\
\hline Papllionaceae & Tephrosia vogelii & Koolein & $\mathrm{Sb}$ & $\mathrm{Ct}, \mathrm{Fm}$ & $\mathrm{Ag}$ \\
\hline Loganiaceae & Nuxia congesta & Ebfian & $\mathrm{Tt}$ & Fo & Fw \\
\hline Euphorbiaceae & Ricinus communis & Jang & $\mathrm{St}, \mathrm{sb}$ & $\mathrm{Ct}$ & $\mathrm{Ag}, \mathrm{Md}$ \\
\hline Papillionaceae & Sesbania sesban & Eyis & $\mathrm{Sb}$ & $\mathrm{Ct}, \mathrm{Fm}$ & $\mathrm{Ag}$ \\
\hline Araliaceae & Schefflera abyssinica & Djia & $\mathrm{Tt}, \mathrm{Ep}$ & Fo & Tc, Ho \\
\hline Ulmaceae & Trema guineensis & Fang & $\mathrm{St}$ & $\mathrm{Sc}$ & $\mathrm{Ag}$ \\
\hline
\end{tabular}

Source: Kilum Ijim Forest Project Plant List. October 1997.

Life form: Tt - tall tree, Ep - tuber / bulb, Sb - herb, St - climber / liana

Habitat: Fo - forest, $\mathrm{Sc}$ - farmland, $\mathrm{Ct}$ - aquatic.

Use: Ag - agro forestry, Tc - wood carving, Ho - honey, Md - medicinal, Fw -firewood, Tr - traditional, Tb - timber.

\subsection{Land Tenure System in Oku}

Traditionally, land acquisition in Oku was through inheritance and leasing. Sons inherited land from the fathers while daughters were expected to get marry and work on their husbands' land. Through the lease method, a person who needs a piece of land takes a fowl and a calabash of fresh palm wine to the land lord. The land landlord receives it and gives the person a piece of land to cultivate. The land could be for permanent or temporary use. In case of temporary use, only food crops are planted on the land. After harvest the farmer gives a share of the harvest to the landlord. If the land leasing is for permanent use, then crops like coffee, bananas and fruit trees can be planted on it. With this method, after cultivation, the farmer is not obliged to give a share of the harvest to the landlord [12]. As a matter of fact, today the land tenure system has greatly witnessed changes. 
Today in Oku, because of rapid population growth and stagnant lands, we have rented and purchased pieces of land. From our fieldwork study only about $20 \%$ of farmers cultivate on rented lands. On such land only food crops such as maize, beans and potatoes are cultivated. More than $80 \%$ of farmers within the study area cultivate on family land, inherited land or purchased land.

\subsection{Land Ownership and Exploitation Within the Context of Transformation}

However these traditional land acquisition methods have gradually given way to the legal system of obtaining land documents. Individual ownership of land today is backed by a land certificate. This is the only legal document testifying land ownership. In this light, most farmers are now encouraged to process legal documents for land ownership to avoid conflicts. Farmers in Oku can now boast of owning their own farm lands. Individual land could be acquired through buying or inheritance. Once the conditions of ownership become clear, the individual can then cultivate food crops and even perennial plant on this piece of land. From Our findings in the field, 70\% of farmers cultivate on the individual plots. From this number only about $12 \%$ can boast of having legal documents attesting their ownership of the land. A good number of these individuals were aged 45 and above [13]. Family plots constitute a majority of the number of plots under cultivation within the study area. A good number of farmers that is women cultivate on their husbands' farms. In Oku, women do not own land. They simply cultivate their husbands' farms and the harvest is for the entire family's consumption. Family owned farms make up about $80 \%$ of the total number of farms cultivated in Oku. On these farms, both food crops and, fruit trees and soil fertilizing trees are largely found. Most of these farmers apply chemical fertilisers to boost their production. More than $90 \%$ of the farmers in Oku are willing to plant and retain trees, and take care of those planted; they should be encouraged by the government to do so. Seedlings and seeds should be distributed to farmers. Those taking care of planted trees should be compensated, while government policies in favour of tree planting should be brought to the door step of the farmers. Incentives and loans should be given to those willing to plant trees.

\subsection{Oku Fon's Palace and Its Institutions}

Located at the road junction leading to Mbam in the north and Jikijem to the west from Manchok, the Oku fon's palace is a centre for both traditional politics and diplomacy. The palace is viewed as the first compound in Oku land. What draws our attention is the arrangements of building structures making up the peoples palace. At the main entrance is the thatched house locally called nda meweyse. Meweyse is the name of a traditional dance from Jikijem. It is in this house that guns are loaded for firing during funerals in the palace [14]. This house is renovated only at the passing away of a fon. It is flanked on both sides by two long buildings, standing parallel to the public hall and its open court yard. Behind the public hall is located a small courtyard hosting a traditionally skewed rostrum from where the fon addresses small groups of visitors to the palace. It is made up of diagonally overlapping and criss-crossing knitted bamboo stuck with mud. In this rostrum is found a royal throne [15]. The layout of the palace in grass fields palaces and particularly that of Oku modifies human structures on the landscape.

\section{Conclusion}

The planting of trees within the study area greatly contributes in changing the panoramic view of Oku. This adds more beauty on the landscape. The steep gradient nature of Oku can be adequately maintained through the act of planting trees along the slopes. This assures a topo-stability of the area. To curb the advance degradation of the forest for individual needs for wood, the landscape is modified with the planting of trees needed to satisfy individual demands. The major reason for this transformation remains the cultural values attached to trees by the growing Oku population. The mosaic nature of trees on the landscape changes the appearance of the entire area. In a nutshell, rural landscape transformation in Oku is linked to the planting of trees along the slopes of mountain area and the springing up of modern structures. One actually confirms this with the numerous tree nursery groups dotted within the locality.

\section{References}

[1] NDIKINTUM J., N., 2000, The Impact of Population Growth and Pressure on Agricultural Land in Oku sub Division NWP, DIPES II Memoir ENS Yaoundé.

[2] GODWILL Tobouah, MOUPOU Moise, (2019). Perceptions and Reality of Agro Forestry Practices in Oku, Cameroon. Journal of Human Resource Management. Vol. 7, No. 4, 2019, pp. 78-86. doi: 10.11648/j.jhrm.20190704.11.

[3] GODWILL Tobouah, (2015), Agro Forestry Practices in Oku Sub-Division: An Impetus to Food Supply and Rural landscape Transformation. Masters Dissertation, Department of Geography. University of Yaounde 1. 149P.

[4] FOGWE Zephania N, (1997), Landscape Degradation on the Kom Highlands (North West Province of Cameroon); An Environmental Assessment. Doctorat de $3^{\text {eme }}$ cycle. Department of Geography, University of Yaounde 1, 341P.

[5] NCHAMCHAM Nsungnen O., (2015), The Contribution Of Common Initiative Groups To Agricultural Production In Oku Sub-Division, University of Bamenda 91.

[6] MACLEOD H, (1987). The Conservation of Oku Mountain Forest. ICPB. Study report $\mathrm{N}^{\circ} 15$ Cambridge.

[7] CHEEK M., GOSLING G., POLlARD B., and PATO A., J., (1998), Checklist of the flora of Mount Oku. Working document RBG Kew.

[8] FORBOSEL P., and MAISELS (1999), Habitat Preferences of Common Montane. 
[9] ENCHAW Gabriel B., (2004), Major Conservation Strategies Adopted for the Sustainable Management of Natural Resources in the Kilum-Ijim Forest Project Area, N. W. P of Cameroon, DEA in Geography, University of Yaoundé 1, 93P.

[10] YENGO Genesis T., (1998). Wood carving in Oku: An Economic Activity in Expansion DIPES II Dissertation ENS Yaoundé 1, 130P

[11] CAMGEW (2012) Report: Success Story.

[12] HAWKINS R., and Brunt, (1965), The Soils and Ecology of West Cameroon, Volume 1, FAO, Rome, 212P.
[13] GODWILL Tobouah, NCHAMCHAM Olive (2019). Common Initiative Groups (CIGs) Enhancement in Agricultural Production in Oku, Cameroon. International Journal of Sustainable Development Research, Vol. 5, No. 3, 2019, pp. 71-78. doi: 10.11648/j.ijsdr.20190503.12.

[14] GODWILL Tobouah, (2019). Productivity Challenge of Soils Along the Slopes of Mount Oku in Cameroon. Fluid Mechanics. Vol. 5, No. 1, 2019, pp. 1-7. doi: 10.11648/j.fm.20190501.11.

[15] GEORGE Ngek D., (2016), Land Tenure Dynamics in Oku Sub-Division, NWR of Cameroon, Masters Dissertation, Department of Sociology. University of Yaounde 1. 141P. 